\title{
One-pot Enzymatic Synthesis of UDP-D-glucose from UMP and Glucose-1-phosphate Using an ATP Regeneration System
}

\author{
Hei Chan Lee, Seung-Don Lee, Jae Kyung Sohng and Kwangkyoung Liou* \\ Institute of Biomolecule Reconstruction, Sun Moon University, Chungnam 336-708, Korea
}

Received 14 August 2003, Accepted 27 January 2004

\begin{abstract}
Glucose-1-phosphate uridylyltransferase from $E$. coli K12 was used to convert uridine-5' -triphosphate and glucose-1phosphate to UDP-D-glucose. The conversion was efficient and completed within 5 minutes under the employed conditions. In addition, thymidine-5'-monophosphate kinase and acetate kinase were proven to be non-specific, converting udridine-5'-monophosphate to uridine-5'triphosphate with $55 \%$ conversion after $6 \mathrm{~h}$, which was much slower than the production of TTP under the same conditions (complete conversion within one hour). Since these two reactions could proceed under the same conditions, a one-pot synthesis of UDP-D-glucose with ATP regeneration was designed from easily available starting materials, and conversion up to $40 \%$ by HPLC peak integration was achieved given a reaction time of $4 \mathrm{~h}$.
\end{abstract}

Keywords: ACK, ATP-regeneration, One-pot synthesis, TMK, UDP-D-glucose, UMP and UTP

\section{Introduction}

Glucose-1-phosphate uridylyltransferase, which catalyzes the conversion of glucose-1-phosphate and UTP to UDP-Dglucose, is widely distributed in animals, plants and microorganisms. The product, UDP-D-glucose, is then used as a glucosyl donor for the biosynthesis of various carbohydrates, such as the cell envelope of Escherichia coli, lipopolysaccharide, capsular polysaccharide, and membranederived oligosaccharides (Audrey et al. 1994). In addition, it is an essential intermediate for the growth on galactose and trehalose, including the synthesis of trehalose. UDP-Dglucose is also considered to be the glucosyl donor for glycogen synthesis in mammalian cells, but ADP-D-glucose

*To whom correspondence should be addressed.

Fax: 82-41-544-2919

E-mail: liou@sunmoon.ac.kr or UDP-D-glucose can serve as glucosyl donors in eukaryotic microorganisms and plants (Magee et al., 2001). Several reports have suggested that the bacterial synthesis of UDP-Dglucose is involved in osmotolerance, thermotolerance, and tolerance to environmental stress (Yamashita et al., 1998).

To produce this valuable UDP-D-glucose, a one-pot reaction system with ATP regeneration was designed, in which easily available UMP and glucose-1-phosphate were used as starting materials (Scheme 1).

\section{Materials and Methods}

Materials and plasmids All chemicals used in this study were purchased from Sigma (St. Louis, USA). The disodium salt of UMP, lithium potassium salt of acetylphosphate, disodium salt of glucose-1-phosphate, disodium salt of ATP, and $\mathrm{MgCl}_{2} 6 \mathrm{H}_{2} \mathrm{O}$ were used as purchased for the enzyme reaction. The enzymes for DNA manipulations were from TAKARA (Shiga, Japan). Primers were synthesized by GenoTec (Daejeon, Korea), and the pGME-T easy vector system was from Promega (Madison, USA). pET32a and $E$. coli BL21(DE3) were from Novagen (La Jolla, USA), and pGEM3Zf was purchased from Promega. Cloning and transformation techniques described by Sambrook et al. (1989) were adapted for this study. The plasmid pET15b containing the pBR322 replication origin and the ampicillin resistance gene was used for cloning the TMP kinase gene, and the plasmid pET24ma containing the p15A origin and kanamycin resistance gene was used for cloning acetate kinase (E.C.2.7.2.1). The TMP kinase (E.C.2.7.4.9), acetate kinase, and the UDP-D-glucose synthase (E.C.2.7.7.12) genes were all amplified by PCR using the genomic DNA of E. coli K12 as a template. All the genes were cloned under the control of the $T_{7}$ promoter.

Construction of expression vector Glucose-1-phosphate uridylyltransferase gene ( $\mathrm{gal} U$ ) from $E$. coli $\mathrm{K} 12$ was cloned to a cloning vector by PCR with two mutated primers complementary to the $\mathrm{N}$ - and C-terminal encoding regions of the gene (Audrey et al., 1994). A modified forward primer was designed for PCR amplification of the galU coding region, which included a BamH I 


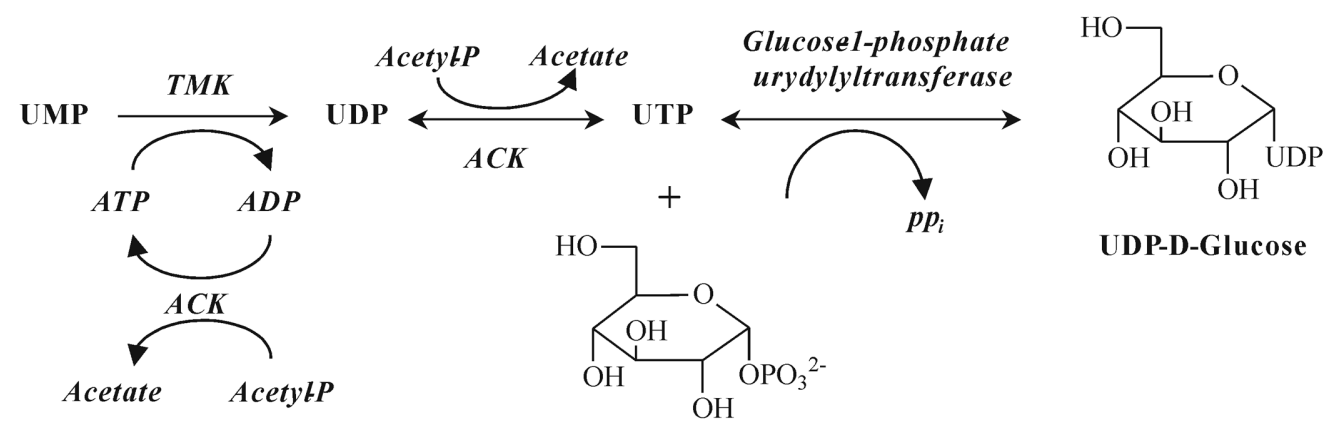

Glucose1-Phosphate

Scheme 1. Enzymatic pathway for the one-pot synthesis of UDP-D-glucose.

site and the ATG start codon (5'-ACGGATCCATGGCTGCCATTA ATA-3'). The reverse primer was a 27 base oligonucleotide containing a Hind III site (5'-CTAAGCTTTTACTTCTTAATGCCC ATC-3'). The PCR product of the expected size $(1.0 \mathrm{~kb})$ was digested with BamH I and Hind III (Jeong and Han 2001). The double digested PCR product was then ligated into the BamH I and Hind III sites of cloning vector pGEM-32f (pLSD-1), and expression vector $\mathrm{pET} 32 \mathrm{a}$ (pLSD1-3).

Cultures and expression All the plasmids above were transformed into $E$. coli BL21 (DE3), which was grown aerobically in $50 \mathrm{ml}$ of Luria broth(LB) using a $250 \mathrm{ml}$ shaking flask. The cells containing TMP kinase, acetate kinase, and glucose-1-phosphate uridylyltransferase were grown to an $\mathrm{OD}_{600}$ of 0.5 at $37^{\circ} \mathrm{C}$ using $0.5 \mathrm{mM}$ isopropyl-D-thiogalactopyranoside (IPTG) for the induction. Cells were harvested, and pelleted after $c a .10 \mathrm{~h}$ of culture. Crude extracts were obtained by sonicating the cell suspension in $50 \mathrm{mM}$ Tris- $\mathrm{HCl}$ buffer $(\mathrm{pH} 7.5)$ containing $1 \mathrm{mM}$ DTT and $1 \mathrm{mM}$ PMSF, The lysate was then centrifuged at 15,000 $\mathrm{g}$ for $30 \mathrm{~min}$ at $4^{\circ} \mathrm{C}$, and the precipitate was discarded.

Enzyme assay All enzyme activities were determined in $50 \mathrm{mM}$ Tris- $\mathrm{HCl}$ buffer $(\mathrm{pH} 7.5)$ at $37^{\circ} \mathrm{C}$. One unit of enzyme activity was defined as the amount catalyzing the formation of $1 \mu \mathrm{mol}$ of product per min (Kim et al., 2002). TMP kinase activity was assayed using $5 \mathrm{mM}$ TMP, $5 \mathrm{mM}$ ATP and $20 \mathrm{mM} \mathrm{MgCl}_{2}$. Acetate kinase activity was assayed using $5 \mathrm{mM}$ TDP, $20 \mathrm{mM}$ acetylphosphate and $20 \mathrm{mM} \mathrm{MgCl}_{2}$. And, glucose-1-phosphate uridylyltransferase activity was assayed using $5 \mathrm{mM}$ UTP, $20 \mathrm{mM}$ glucose-1-phosphate and $20 \mathrm{mM} \mathrm{MgCl}$.

Production of UDP-D-glucose The concentrations of UMP, acetylphosphate, glucose-1-phosphate, ATP and $\mathrm{MgCl}_{2}$ were 20 $\mathrm{mM}, 100 \mathrm{mM}, 80 \mathrm{mM}, 1 \mathrm{mM}$ and $20 \mathrm{mM}$, respectively. The synthesis reaction was initiated by the addition of 0.5 units of TMP kinase and glucose-1-phosphate uridylyltransferase, and 50 units of acetate kinase at $37^{\circ} \mathrm{C}$ for $30 \mathrm{~min}(\mathrm{Oh}$ et al., 2003). The acetate kinase was used in excess to ensure efficient ATP regeneration and to prevent the accumulation of UDP. The reaction was stopped by heating the reaction mixture at $100^{\circ} \mathrm{C}$ for $40 \mathrm{~s}$.

HPLC analysis Various nucleotides and UDP-D-glucose were analyzed by HPLC using a strong anion exchange column
$\left(\mathrm{XTerra}^{\mathrm{TM}} \mathrm{RP}_{18}, 4.6 \times 250 \mathrm{~mm}, 5 \mu \mathrm{m}\right.$ particle size) with $100 \mathrm{mM}$ potassium phosphate buffer $(\mathrm{pH} 3.5)$ : Methanol = $95: 5(\mathrm{v} / \mathrm{v})$. The eluted nucleotides were monitored by absorbance at $270 \mathrm{~nm}$ at a flow rate of $1.0 \mathrm{ml} / \mathrm{min}$.

\section{Results and discussions}

Expression and identification of the glucose-1-phosphate uridylyltransferase (galU) The nucleotide sequence of glucose-1-phosphate uridylyltransferase gene ( $\mathrm{gal}$ ) obtained using optimized PCR conditions (denaturing : annealing: polymerization; $95: 55: 72^{\circ} \mathrm{C}$, respectively) was confirmed by sequencing. Plasmid pLSD1-3 was transformed into $E$. coli BL21 (DE3). Induction with IPTG of cells transformed with pLSD1-3 resulted in the production of the $55 \mathrm{kDa}$ protein comprised of GalU (909 bp, $33 \mathrm{kDa})$ and fusion protein. Its molecular mass was in accordance with the predicted molecular mass of the deduced GalU protein (Fig. 1).

Characterization of the enzyme and production of UDPD-glucose Since the over-expressed enzyme (GalU) catalyzes the conversion of UTP and glucose-1-phosphate to UDP-D-glucose, this reaction was performed using $20 \mathrm{mM}$ $\mathrm{MgCl}_{2}, 9.0 \mathrm{mM}$ Tris-HCl buffer solution ( $\left.\mathrm{pH} 7.5\right), 50 \mathrm{mM}$ glucose-1-phosphate, $20 \mathrm{mM} \mathrm{UTP,} 60 \mathrm{u}$ GalU and $1.8 \mathrm{u}$ inorganic pyrophosphatase at $37^{\circ} \mathrm{C}$ to confirm the activity of the expressed GalU. Reactions were quenched by heating the mixture with boiling water for $40 \mathrm{~s}$, and cooled in an ice-water bath. This reaction mixture was then centrifuged and only the supernatant was used for HPLC analysis. Conversion of UTP and glucose-1-phosphate to UDP-D-glucose was almost complete within $5 \mathrm{~min}$ (100\%), and slow UDP-D-glucose decomposition was observed after $10 \mathrm{~min}$ of reaction as shown in Fig. 2. Parallel experiments using thymidine-5'triphosphate (TTP) instead of UTP also showed a high conversion to TDP-D-glucose, indicating that this glucose-1phosphate uridylyltransferase is non-specific (Fig. 2).

Thymidine-5'-monophosphate kinase (TMK) and acetate kinase (ACK) from E. coli $\mathrm{K} 12$ catalyse the conversion of TMP to TTP, and thus we adapted these enzymes to perform 


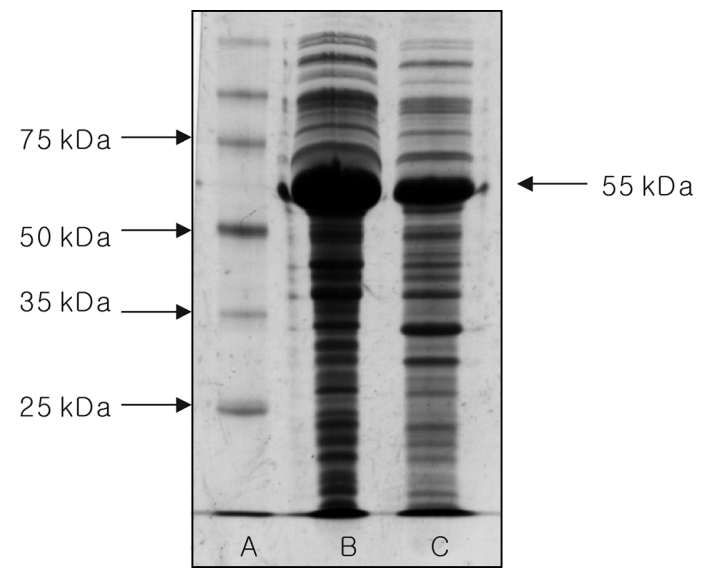

Fig. 1. Identification of the over-expressed glucose-1-phosphate uridylyltransferase (GalU) by SDS-PAGE: Lane A, protein marker; Lane B, insoluble; Lane C, soluble.

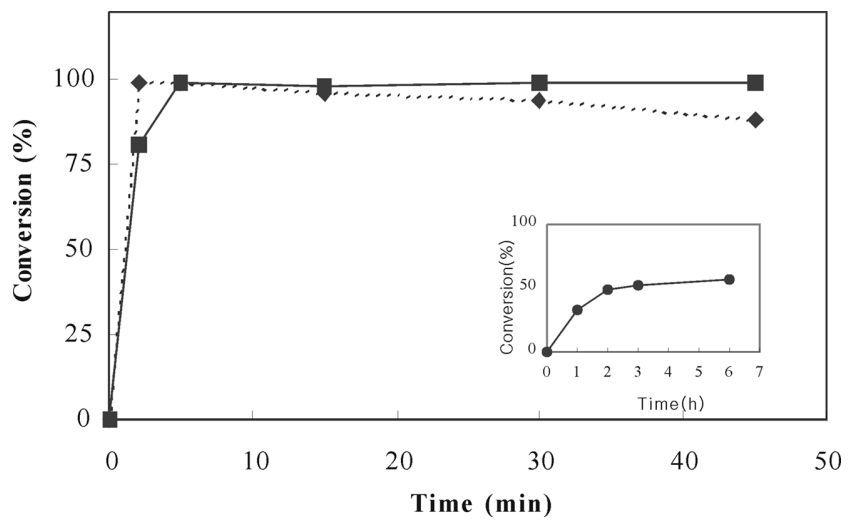

Fig. 2. Conversion of UTP/TTP and glucose-1-phosphate to UDP-D-glucose/TDP-D-glucose by GalU: $\boldsymbol{\imath}$, UTP; $\boldsymbol{\square}$, TTP [Inset shows conversion of UMP to UTP].

the conversion of UMP to UTP due to the current unavailability of uridine-5'-monophospahte kinase, and used

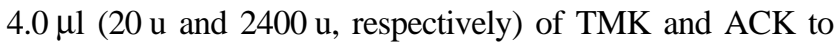
convert UMP to UTP using $20 \mathrm{mM}$ UMP, $1.0 \mathrm{mM}$ ATP, 100 $\mathrm{mM}$ acetyl phosphate, $20 \mathrm{mM} \mathrm{MgCl}_{2}$, and $30 \mathrm{mM}$ Tris- $\mathrm{HCl}$ buffer ( $\mathrm{pH} 7.5$ ) at $37^{\circ} \mathrm{C}$ using the same procedure. This reaction was rather slow compared to the conversion of TMP to TTP, where complete conversion was accomplished within one hour, reaching 55\% conversion after $6 \mathrm{~h}$ (Fig. 2 inset). Since this slow conversion could be expected to have an affect on the conversion of UTP and glucose-1-phosphate to UDPD-glucose by GalU, an intensive search for uridine-5'phosphate kinase is in progress.

Since both the conversion of UTP and glucose-1-phosphate to UDP-D-glucose by GalU, and that of UMP to UTP by TMK and ACK, could be performed under almost the same reaction conditions, a one-pot synthesis of UDP-D-glucose from easily available starting materials was designed (Scheme 1), according to the reaction conditions described in "Materials and Methods". Since this reaction was expected to
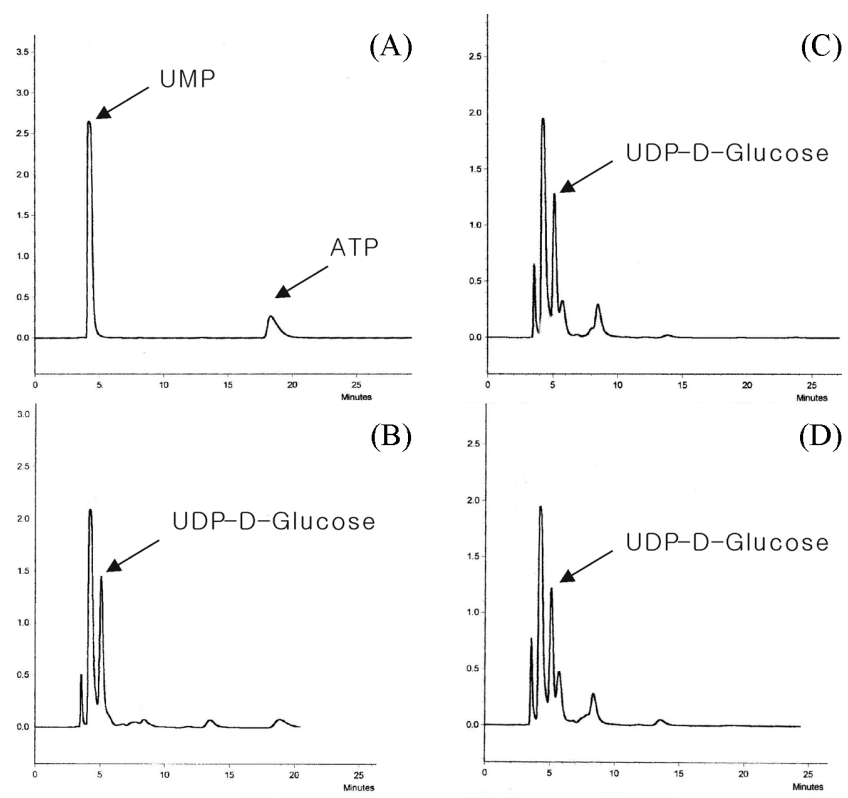

Fig. 3. HPLC diagrams for the production of UDP-D-glucose: (A) before induction, (B) after $1 \mathrm{~h},(\mathrm{C})$ after $2 \mathrm{~h},(\mathrm{D})$ after $3 \mathrm{~h}$.

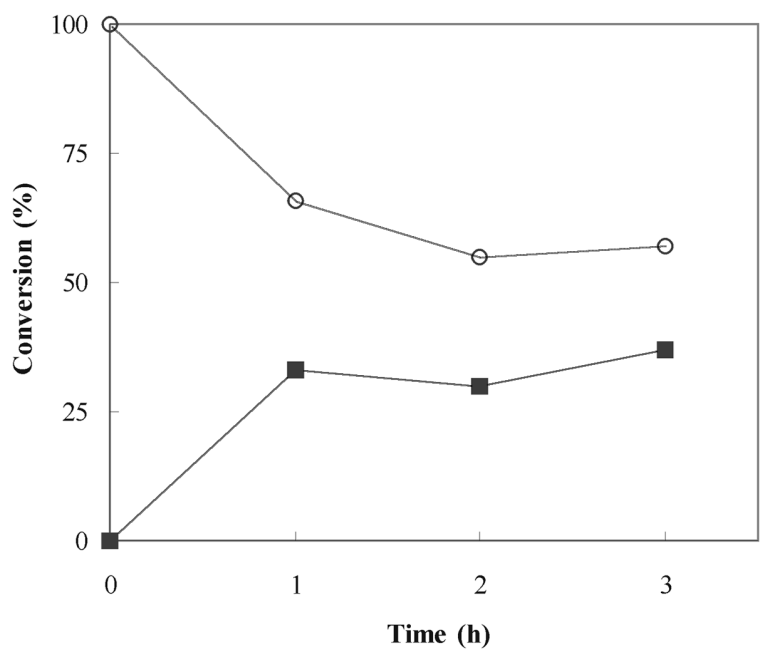

Fig. 4. Conversion of UMP and glucose-1-phosphate to UDP-Dglucose: $\bigcirc$, Consumption of UMP; $\boldsymbol{\square}$, Production of UDP-Dglucose.

proceed slowly due to the non-specificity of the TMK enzyme (instead of UMK), the conversion efficiency was checked every hour according to the same quenching and sampletreating procedure (Fig. 3). The conversion turned out to be slow during the initial conversion (during $1 \mathrm{~h}$, Fig. 4), because the reaction from UMP to UTP by TMK and ACK was slow, as shown by Fig. 2 inset, and the conversion seems to reach equilibrium at $\mathrm{ca}$. $40 \%$ conversion (Fig. 4). Further reaction up to $6 \mathrm{~h}$ did not increase conversion. From the result of the conversion experiment of UTP and glucose-1-phosphate to UDP-D-glucose, we expected more conversion to UDP-Dglucose, because the produced UTP would be consumed by 
GalU, which would shift the equilibrium from UMP to UTP. Nevertheless, a one-pot synthesis of UDP-D-glucose was achieved with reasonable conversion efficiency from cheap starting materials. We are now trying to find a specific enzyme for converting UMP to UTP, and on further optimizing the one-pot reaction conditions to enhance conversion efficiency.

Acknowledgments This work was supported by the $21 \mathrm{C}$ Frontier Microbial Genomics and Application Center Program of the Korean Ministry of Science and Technology, Grant MG020302 to KL and MG020301 to JKS.

\section{References}

Audrey, C. W., Quingyen, L., Marilynn, K. R. and Eugene, P. K. (1994) UTP: $\alpha$-D-glucose-1-phosphate uridylyltransferase of Escherichia coli: Isolation and DNA sequence of the GalU gene and purification of the enzyme. J. Bacteriol. 176, 26112618.

Jeong, E. and Han, O. (2001) Purification and characterization of
Bacillus subtilis proptoporphyrinogen oxidase and preequilibrium behavior during oxidation of protoporphyrinogen IX. J. Biochem. Mol. Biol. 34, 39-42.

Kim, S. -K., Park, P. -J., Kim, J. -B. and Shahidi, P. (2002) Purification and characterization of a collagenolytic protease from the filefish. Novoden modestrus, J. Biochem. Mol. Biol. 35, 165-171.

Magee, C., Nurminskaya, M. and Linsenmayer, T. F. (2001) UDPglucose pyrophosphorylase: up-regulation in hypertrophic cartilage and role in hyaluronan synthesis. Biochem. J. 360, 667-674.

Oh, J., Kim, B. -G., Sohng, J. K., Liou, K. and Lee, H. C. (2003) One-pot enzymatic production of dTDP-4-keto-6-D-glucose from dTMP and glucose-1-phosphate. Biotech. Bioeng. 84, 452-458.

Sambrook, J., Fritsch, E. F. and Maniatis, T. (1989) Molecular Cloning: A Laboratory Manual, $2^{\text {nd }}$ ed., Cold Spring Habor Laboratory Press, New York, USA

Yamshita, Y., Tsukioka, Y., Nakano, Y., Tomihisa, K., Oho, T. and Koga, T. (1998) Biological functions of UDP-glucose synthesis in Streptococcus mutans, Microbiology 144, 1235-1245. 